\title{
APPLICATION OF UNMANNED AERIAL VEHICLE AS A BASE MAP LAYER IN NEAR-SURFACE GEOPHYSICS
}

\author{
Muhammad Yanis', Faisal Abdullah', ${ }^{1,2}$, Aprilla Anggini Hasibuan', \\ Muzakir Zainal1, Marwan ${ }^{1,2}$ \\ ${ }_{1}^{1}$ Program Studi Teknik Geofisika, Fakultas Teknik, Universitas Syiah Kuala \\ 2Program Studi Fisika, Fakultas MIPA, Universitas Syiah Kuala \\ Jl. Teuku Nyak Arief, Darussalam, Banda Aceh, Aceh 23111, Indonesia \\ e-mail: yanis@unsyiah.ac.id
}

Received: 16 April 2020, Repaired: 12 June 2020, Approved: 03 November 2020

\begin{abstract}
The Geophysical method is operated by using physical parameters above the surface to estimate the subsurface structures. In data interpretation, all 3D surveys, i.e., magnetic, gravity, magnetotelluric, and airborne, are required for geographical conditions in the research area. In a large area, global DEM data is used to explain the field condition, but for local measurement, the data is not efficient due to low resolution $(15-30 \mathrm{~m} / \mathrm{px})$. This research uses UAV technology to produce a high-resolution topography in local Geophysical measurement $(500 \times 600 \mathrm{~m})$. The survey was conducted to map the coal structure in the subsurface. UAV data were also compared to SRTM $(30 \mathrm{~m} / \mathrm{px})$ and DEMNAS $(8 \mathrm{~m} / \mathrm{px})$ as global topography. Based on data processing, the UAV topographic was have a high resolution of $2.5 \mathrm{~cm} / \mathrm{px}$. Comparison of $U A V$ and magnetic data are able to explain a good condition of field measurement than a global DEM data, even in a relatively small area; outcrops of the coal $(50 \times 50 \mathrm{~m})$ can show a good differences contrast of topography. Based on data analysis, we can conclude that UAV technology can interpret the geophysical data measured in a local area.
\end{abstract}

Keywords: UAV, SRTM, Topography, Geophysical Interpretation.

\begin{abstract}
Abstrak
Metode Geofisika bekerja dengan memanfaatkan parameter fisis diatas permukaan untuk pendugaan struktur bawah permukaan. Dalam tahapan interpretasi data, semua pengukuran 3D Geofisika; magnetic, gravity, magnetotelluric, dan airbone sangat membutuhkan keadaan geografis lapangan. Pada area yang luas, data DEM global digunakan untuk menjelaskan deskripsi lapangan, namun untuk pengukuran dekat permukaan yang bersifat lokal, data ini tidaklah efesien, karena resolusi yang relative rendah $(15-30 \mathrm{~m} / \mathrm{px})$. Kami menggunakan teknologi UAV untuk menghasilkan topografi resolusi tinggi pada area pengukuran Geofisika dengan luas $500 \times 600 \mathrm{~m}$, yang disurvei untuk pemetaan batubara dibawah permukaan. Data UAV juga dibandingkan dengan topografi global SRTM $(30 \mathrm{~m} / \mathrm{px})$ dan DEMNAS $(8 \mathrm{~m} / \mathrm{px})$. Hasil pengolahan data menunjukkan data UAV menghasilkan topografi dengan resolusi $2.5 \mathrm{~cm} / p x$. Hasil overlay UAV dengan Geofisika magnetik mampu menjelaskan deskripsi lapangan dengan sangat baik dibandingkan DEM global, bahkan pada area yang relative kecil seperti singkapan batuabara $(50 x 50 \mathrm{~m})$ dapat menunjukkan keadaan perbedaan topografi dengan kontras. Berdasarkan data analysis, topografi UAV sangat potensial digunakan untuk interpretasi data Geofisika dekat permukaan yang diukur pada area yang relative lokal.
\end{abstract}

Kata kunci: UAV, SRTM, Topografi, Interpretasi Geofisika 


\section{INTRODUCTION}

Application of geophysical methods always requires geographical data to explain the field survey's condition as a geological object, outcrops, and elevation to facilitate the geophysical data interpretation (Masoud, 2011). The topographic data from the Digital elevation model (DEM) has been used to study various phenomena in earth science; such as mapping of geological structures (Masoud and Koike, 2006), geomorphology (Bailey et al., 2007), hydrogeology (Valeriano et al., 2006), and also used in natural hazard studies as floods, earthquake, and tsunamis event (Sander, 2007). Furthermore, the topographic data also becomes the main parameter in the geophysical survey, usually used as a base map in magnetic, gravity measurements, and seismological studies. The topographic has been the standard technique for presenting the field data (Yanis et al., 2019; Umar et al., 2018).

Information of spatial geography can be made using the satellite observation data, which may be represented in two dimensions of the earth's surface. Kalaivanan (2014) states the Shuttle Radar Topographic Mission (SRTM) is a useful satellite image used to describe topographic conditions in an area with a resolution of 30 $\mathrm{m}$. For regional measurements $(>1000 \mathrm{~km} 2)$, the SRTM data is applicable. For residual $<1000 \mathrm{~km} 2$, the data is not useful because the relative data distribution is less, and large spatial resolution did not represent the geographical conditions of the survey areafor example, the near-surface geophysics measured in an area of $500 \mathrm{~m} \times 600 \mathrm{~m}$. Moreover, the residual topography is always needed in the near-surface data, which not be solved by global topography. Actually, there are various types of high-resolution satellites available on the internet, such as GeoEye, IKONOS, SPOT-5, and TerraASTER. The satellite data has a resolution of 0.46 meters for 1 pixel, but the data is high at an economical cost and cannot freely access. The relatively expensive data becomes a problem in near-surface geophysics. In contrast, the other factors of the satellite data are a cloud cover, dependence on data providers, and the time or location data, which is not flexible (Shofiyanti, 2011). Moreover, to obtain a high-resolution of topography that provides a representative of the local geographic survey area, a technology of aerial photography is used from drone equipment or Unmanned Aerial Vehicle. UAV technology is increasingly applied in several geological investigations (Blistan, 2016). UAV applications can be paired with high-resolution digital cameras that can produce a digital orthophoto, DEM, Digital Terrain Model (DTM), Digital Surface Model; (DSM), and 3D models of the geological objects. This system is very useful for many topographic mapping, especially for residual areas that can reduce the timeconsuming and economical cost. The UAV is also possible to be measured in cloud-free conditions that affected the results of topographic data (Ahmad et al. 2008).

UAV applications have been widely used in various aspects; for example, Chi et al. (2016) to produce high topographic maps of the Errn river flow in Tainan, Taiwan, and also Mancini et al. (2013) have used hex copter-type UAVs for observation of sand dunes in the area of the North Adriatic coast in Ravenna, Italy, these topographic data are beneficial for use in a smaller or local study area. This research used the UAV system to produce a high-resolution of topography data as a base map to interpret near-surface geophysical methods. The case study is located in Lam Apeung Village, Aceh Besar, Aceh Province, with an area of $500 \times 600 \mathrm{~m}$. Several geophysical techniques have been measured at this location, such as resistivity, gravity, and magnetic, to observe coal distribution under the surface. The research area is shown in Figure 1. The DJI Mavic Pro is used to capture object images with 
overlapping for 80 - 100\%. This equipment has a camera resolution of $12 \mathrm{MP}$, which is possible to produce a spatial resolution of $0.15-0.25 \mathrm{~m} / \mathrm{px}$ for a flight distance of $100 \mathrm{~m}$.
Besides, for data comparison, the UAV system will be compared with a global topography such as SRTM $(30 \mathrm{~m} / \mathrm{px})$ and DEMNAS (8 m/px) data.
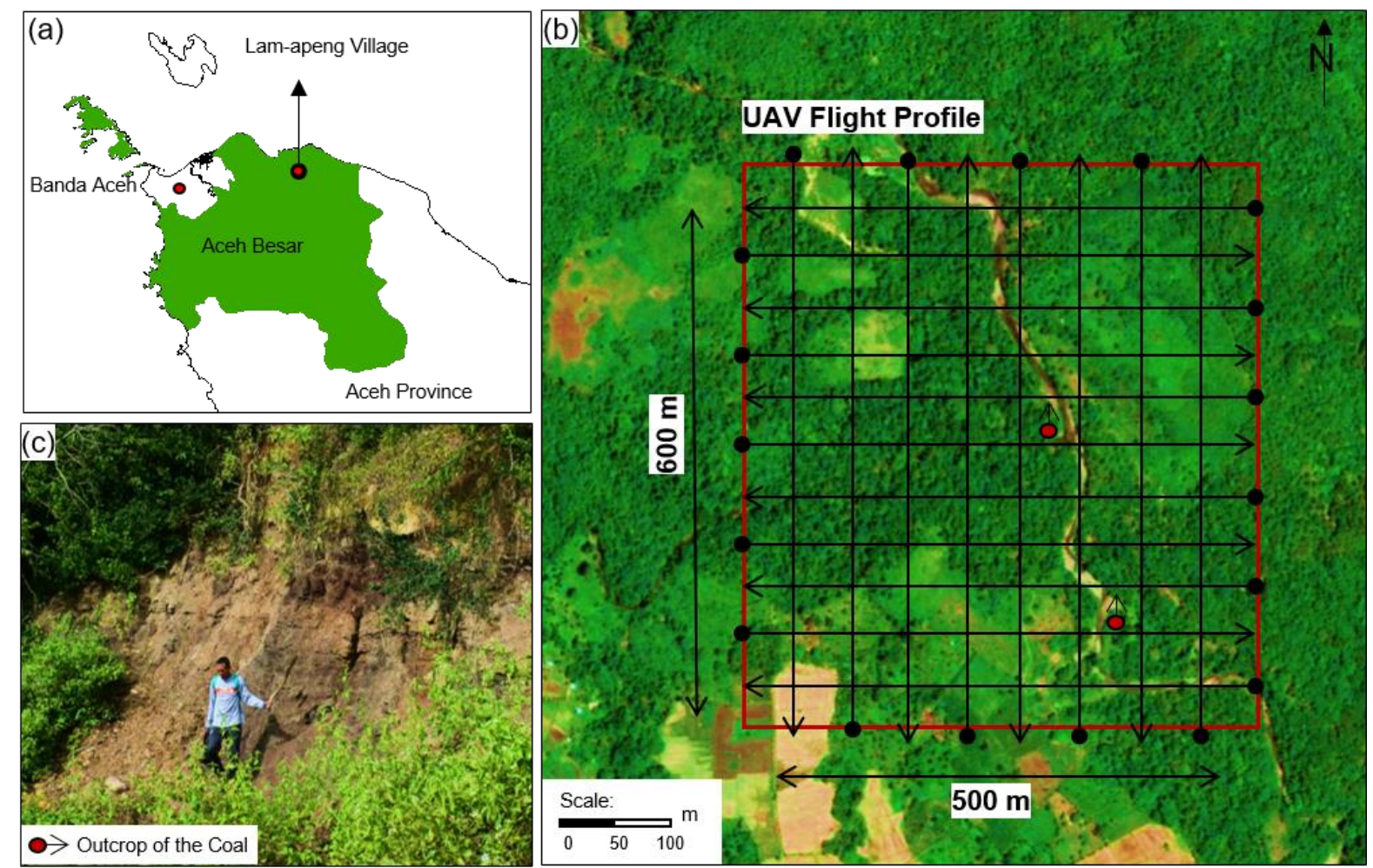

Figure 1. (a) The research location is in Lam Apeng Village, Aceh Besar; $\pm 50 \mathrm{~km}$ from Banda Aceh. (b) Shows a UAV flight route of 500×600 m area. The red box is the measurement area for the geophysical method, while the red circle is the location for the coal outcrop shown in

Figure (c).

\section{METHOD AND DATA OBSERVATION}

Digital Elevation Model (DEM) is a technique to store topographic data into the $X$ coordinates as a latitude function. The $Y$ coordinates as longitude and $\mathrm{Z}$ coordinates as height (mostly in mean sea level unit or MSL), representing the topographic condition from the survey area. The DEM in this research was derived from a UAV made by the DJI Mavic Pro as a multicopter drone type. In order to cover the entire measurement area (as shown by the red box in Figure 1.c), the drone was flown at an altitude of 100 meters and controlled through the Pix4D mapper application. The flight had successfully obtained 630 photos covering an area of $500 \times 600$ meters square, with a duration of \pm 15 minutes. The specific instruments used in the flight are shown in
Table 1. The photos were processed using an open-source software Drone Mappers with SFM (structure from motion) technique. The software is able to model objects from twodimensional images into three-dimensional shapes. The images were then processed using high-quality settings that included aligning photos, building the dense cloud, and mesh to generate the DEM data and orthomosaics from all pictures. In order to obtain the comprehensive results, the data obtained from the UAV will be compared with Shuttle Radar Topography Mission (SRTM) satellites and National DEM data, which can be accessed free of charge.

The SRTM data were downloaded from the USGS website earthexplorer.usgs.gov with a resolution of 
$30 \mathrm{~m}$, while the National DEM data were downloaded from the BIG website tides.big.go.id/DEMNAS with a resolution of $8 \mathrm{~m} / \mathrm{px}$. The SRTM data is obtained through the Space Shuttle Endeavor satellite, equipped with two antenna panels. This satellite was flown in 2000 with an altitude of $233 \mathrm{~km}$ and a tilt of 57 degrees. Endeavor orbits Earth 16 times each day during its 11day mission, completing 176 orbits. SRTM has managed to collect radar data of more than $80 \%$ of the earth's land surface between $60^{\circ}$ North latitude and $56^{\circ}$ South latitude with data points every one arc-second about 30 meters (Masoud and Koike, 2011).

Table 1. Instruments of the research

\begin{tabular}{|c|c|c|c|}
\hline No & Instrument & & Specifications \\
\hline 1 & Drone Mavic Pro Platinum & $\begin{array}{l}\text { ISO } \\
\text { Sensor } \\
\text { Operating Temperature Range } \\
\text { Satellite Positioning Systems } \\
\text { Maximum Takeoff Altitude }\end{array}$ & $\begin{array}{l}305 \times 204 \times 85 \mathrm{~mm} \\
743 \text { gram } \\
65 \mathrm{~km} / \text { hours } \\
27 \text { minutes } \\
4000 \times 3000 \\
\text { C4K: } 4096 \times 216024 \mathrm{p} \\
4 \mathrm{~K}: 3840 \times 216024 / 25 / 30 \mathrm{p} \\
2.7 \mathrm{~K}: 2720 \times 153024 / 25 / 30 \mathrm{p} \\
\text { FHD:1920×1080 } \\
100-1600 \\
1 / 2.3^{\prime \prime}(\mathrm{CMOS}), \text { Effective } \\
\text { piksels:12.35M } \\
32^{\circ} \text { to } 104^{\circ} \mathrm{F}\left(0^{\circ} \text { to } 40^{\circ} \mathrm{C}\right) \\
\text { GPS / GLONASS } \\
16404 \text { feet }(5000 \mathrm{~m})\end{array}$ \\
\hline 2 & Software Pix4D & Mapper version & \\
\hline 3 & Drone Mapper & $\begin{array}{l}\text { Desktop photogrammetry } \\
\text { software. Processing of } \\
\text { orthomosaic, DEM, DTM, and } \\
\text { Point Cloud Generation }\end{array}$ & \\
\hline
\end{tabular}

Source: DJI Release Note, 2018

The SRTM and DEMNAS data were then processed and cropped to have the same area as with the UAV data set. The data then converted into a hillshade using the 3D Analyst toolbox in ArcGIS 10.5 software by ESRI. Specifically, the flow chart of the UAV data processing and satellite topography is shown in Figure 2. The hillshade is the provision of different angles of light so that it is useful for sharpening the visualization of a surface to display a more representative image. The purpose of a hillshade process is to get a 3D effect of images so that the relief shape is visible, making the visual appearance of an object more visible. The DEMNAS data with better resolution (8 meters/px) is built from several satellites, such as IFSAR (5 $\mathrm{m}$ resolution), TERRASAR$X$ (5 $\mathrm{m}$ resolution), and ALOS PALSAR (11.25m resolution) and additional mass point data from stereo-plotting. The spatial resolution of DEMNAS is 0.27-arcsecond using the EGM 2008 vertical datum. If the unit is converted to meters, the value is approximately $8.33 \mathrm{~m} / \mathrm{px}$. Sumatra's validation results show that the accuracy of DEMNAS is better than the high data model formed from the mass point, spot height, and breakline (BIG, 2014). 


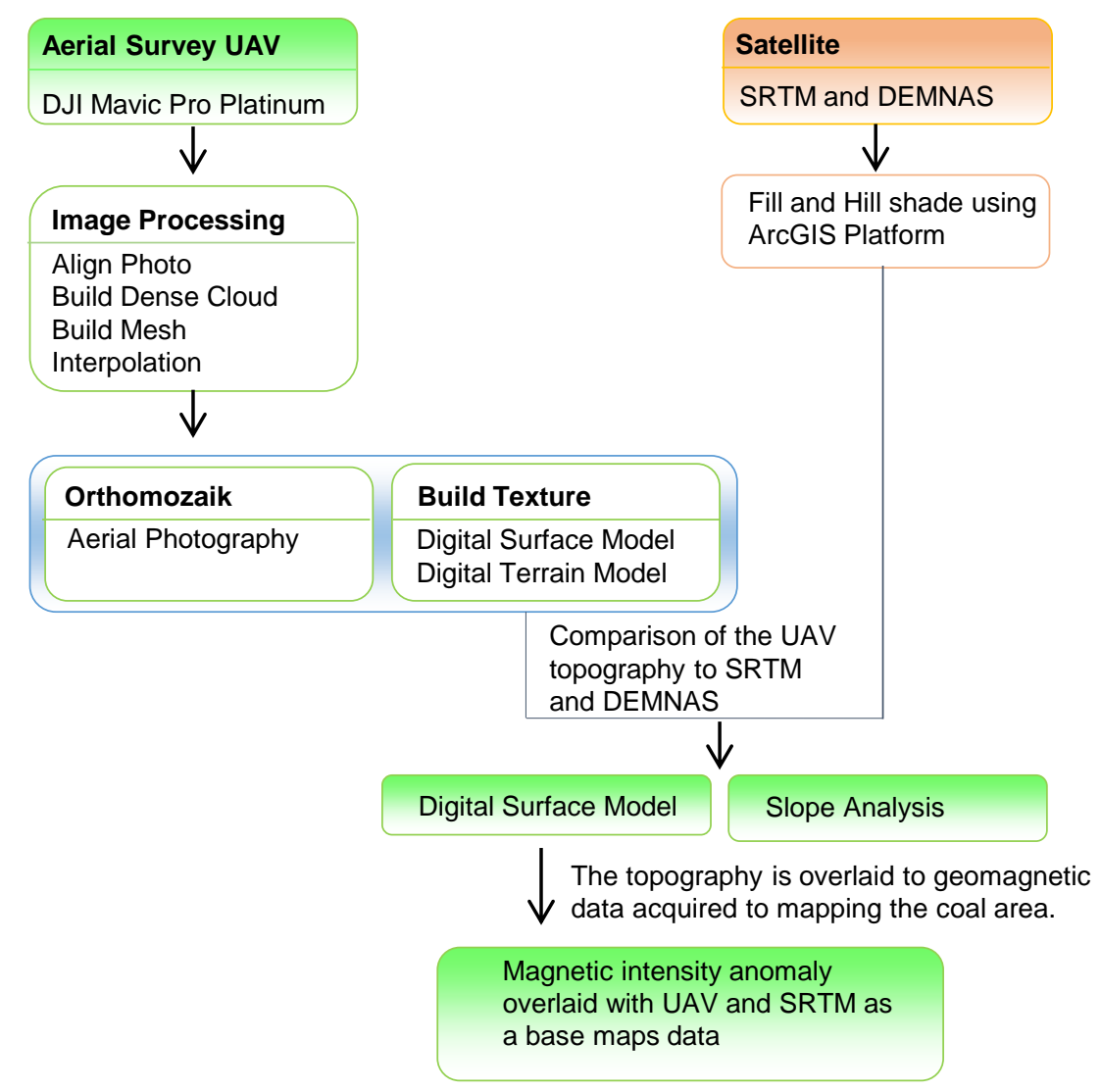

Figure 2. Flow chart of the topography comparison from the UAV instrument and satellite data (SRTM and DEMNAS) as a base map in measuring magnetic geophysical data.

\section{RESULTS AND DISCUSSION}

The processing results of $630 \mathrm{UAV}$ data to become the topographic data in the form of a Digital Terrain Model (DTM), Digital Surface Model (DSM), and orthomozaik show that the difference between these two elevation data lies in the height assumption generated by DTM without following the object's height. In contrast, the calculation of digital elevation on the DSM follows the object's height above the surface (Vallet et al., 2011). However, in this study, the DTM data was not used because it had a lower resolution than the DSM elevation. Figure 3 shows DSM topographical data with $500 \times 600$ meter square in a coal area in Lam Apeng Village, District of Aceh Besar, Aceh Province. Overall, the topographic values obtained are in the range of $120-250 \mathrm{~m}$. The relatively low values are located in river areas, while high values are in community plantation areas. Besides being able to distinguish the location of the river from the surrounding conditions, the data can also recognize the boundaries of the community's rice fields because the topographic data has a resolution of 2.5 $\mathrm{cm} / \mathrm{px}$, which is generated by combining 630 images with a quality of $20 \mathrm{MP}$ (4000 x 3000 pixels).

Besides, the UAV topography data can clearly show the coal outcrop area with a width of $50 \mathrm{~m}$ and a difference in height of up to $30 \mathrm{~m}$, as shown in Figure 3.b. This is verified through documentation in the field outcrop area (Figure 3.c). Simultaneously, a survey of several geophysical methods was carried out, such as magnetic, gravity and resistivity surveys, to estimate the structure of the coal below the surface. According to Marwan et al. (2019), the area's geological structures are generally dominated by rocks originating from volcanic eruptions, namely the Lam Teuba formation. This formation consists of volcanic rocks from andesite to dacite, pumice breccia, tuffs, agglomerates, and young volcanic deposits. Apart from geological information, this high-resolution 
DSM topography is certainly very useful for geophysicists in interpreting geophysical results to the geographical conditions of the survey area.
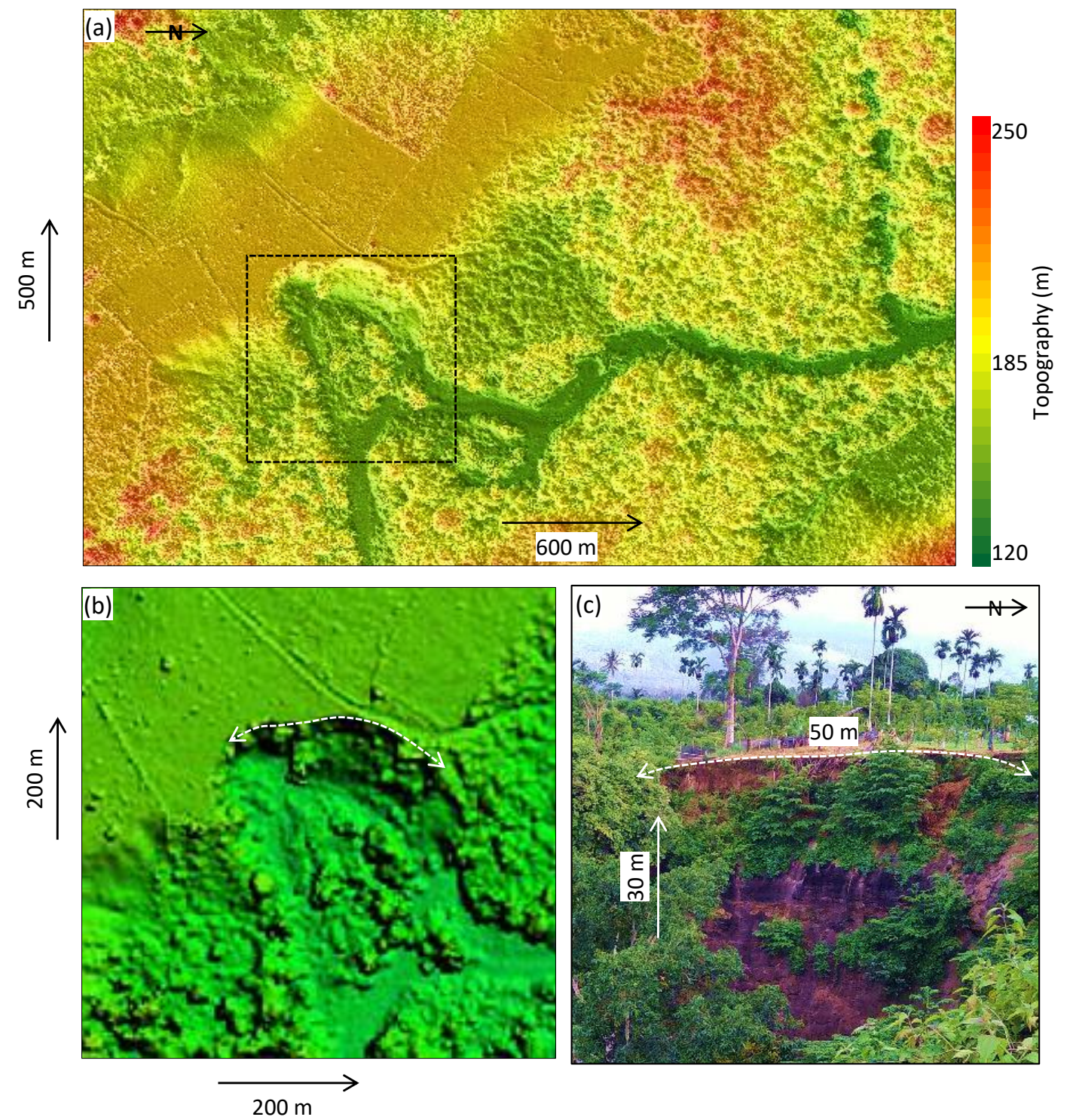

Figure 3. (a) The DEM topographic data generated from UAV images with a resolution of $0.25 \mathrm{~cm} / \mathrm{px}$ with a range of $120-250 \mathrm{~m}$, the area in the black box is the coal outcrop area. (b) The UAV topography data is only presented in the outcrop area. The white line is the area corresponding to the field outcrop, while (c) is a photograph of the outcrop area.

\section{Comparison of UAV to SRTM and} DEMNAS Data

In order to see the difference between UAV topography with the global satellite data, the UAV topography data were compared with the SRTM 1-minute grid (resolution $30 \mathrm{~m}$ ) and the DEMNAS (resolution $8.2 \mathrm{~m}$ ) data. Figure 4 shows the topographic differences resulting from these three data. These topographic data were plotted in the same range, $120-250 \mathrm{~m}$.
Overall, the SRTM and DEMNAS topographical data show a relatively similar pattern. For example, the left and the right sides are dominated by relatively high values, while relatively low values are located in the middle area. However, the patterns produced by these two data are unable to describe the geographical condition of the research area; even to recognize the location and flow of the river 
are challenging. The resolution of these two data causes this problem is relatively large.

The UAV data produced a $2.5 \mathrm{~cm} / \mathrm{px}$ topographic resolution, clearly showing the contrast difference between the river and its surrounding conditions, even for relatively small objects $(1 \times 1 \mathrm{~m})$ such as the rice field dividers, which can be recognized in the UAV data. In general, in the coal outcrop area, the SRTM data shows a round pattern with a relatively low topography value due to the difference in topography connected to the river area. However, in the DEMNAS data, the outcrop topography is separated from the river area. This result shows that the DEM data global is not useful for small local areas. Compared to the area of $500 \times 600$ $\mathrm{m} 2$ or $30,000 \mathrm{~m} 2$, the distribution of SRTM data is 10,000 data points, the DEMNAS data is 37,500 data points, while UAV data is 1.2 million data points with a flight distance of $100 \mathrm{~m}$. UAV data distribution is 1: 120 compared with the SRTM data and 1:32 with the DEMNAS data.

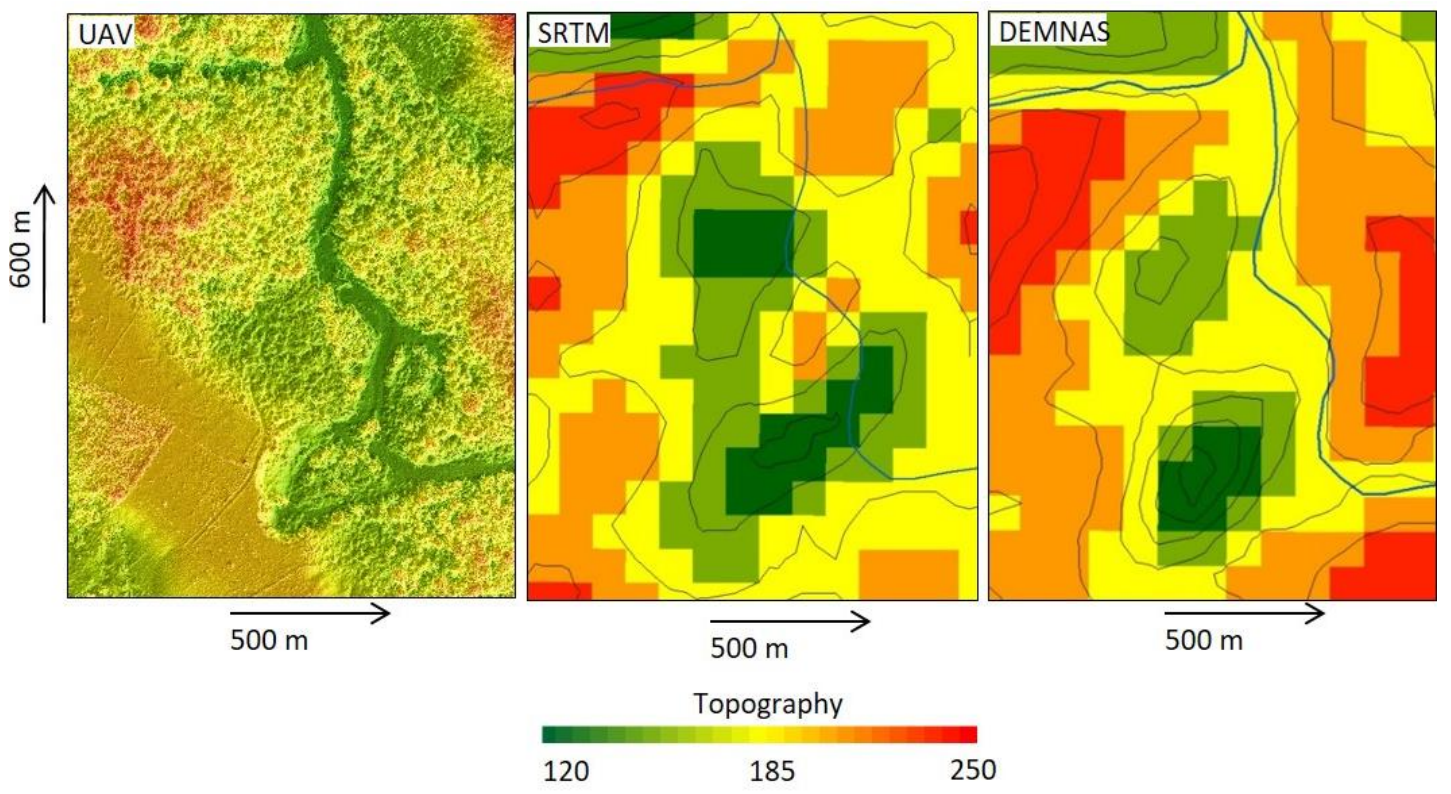

Figure 4. The Comparison of the topographic data produced by (a) UAV drones, (b) Satellite SRTM, and (c) National DEM. These three data are plotted over the same range $120-250 \mathrm{~m}$.

\section{Slope Analysis of UAV and satellite data}

Similar to the global DEM data that allows for further analysis, the UAV topographic data is also allowed for further analysis, such as calculating the slope and comparing it with the SRTM and DEMNAS data. Figure 5 shows the slope analysis of the three DEM data above. The slope values can be determined by the difference between the land surface in the horizontal $(\mathrm{dz} / \mathrm{dx})$ and vertical $(\mathrm{dz} / \mathrm{dy})$ directions from the center point of the maximum data height. Mathematically it can be calculated as follow:

$$
\text { slope }=\operatorname{atan} \sqrt{\left(\frac{d z^{2}}{d x}\right)+\left(\frac{d z^{2}}{d y}\right)} \times 57.295
$$

Where the value of 57,295 is the result of $180 /$ pi.
In order to compare data from different sources, the slope of the UAV and global satellite is plotted in the same range from 0 to 60 degrees. In contrast to the topography data, the slope data obtained from the SRTM satellite is different from the DEMNAS data. For example, the river location is low in the DEMNAS but high on the SRTM, but the slope data obtained from these two sources cannot distinguish relatively small objects such as rivers and rice fields. The resulting slope data is only a response to the hilly areas mostly located on the east and west sides of the survey area, due to the low resolution of both global data, about 30 meters for the SRTM and $8.2 \mathrm{~m}$ for the DEMNAS. Overall, these Global data cannot be used to study a relatively small 
local area $(500 \times 600 \mathrm{~m} 2)$. In contrast, the slope data from the UAV can show a contrasting difference between relatively small objects with surrounding general conditions. For example, a slope value obtained in the river areas is 0 degree, and so does in the rice fields on the west side. However, in the hill area, which is generally characterized by various topographies, the slopes are usually high up to 60 degrees.
In the coal outcrop area (white line area in Figure 5), the UAV data can also show a pattern of slope heights up to 60 degrees, which is also surrounded by a relatively flat area with a slope of 0 degrees. This is consistent with field documentation taken on the outcrop area. Besides, the slope data from the DEMNAS also show relatively high values in the outcrop area, while the SRTM data is unable to show the slope contrast in that area.
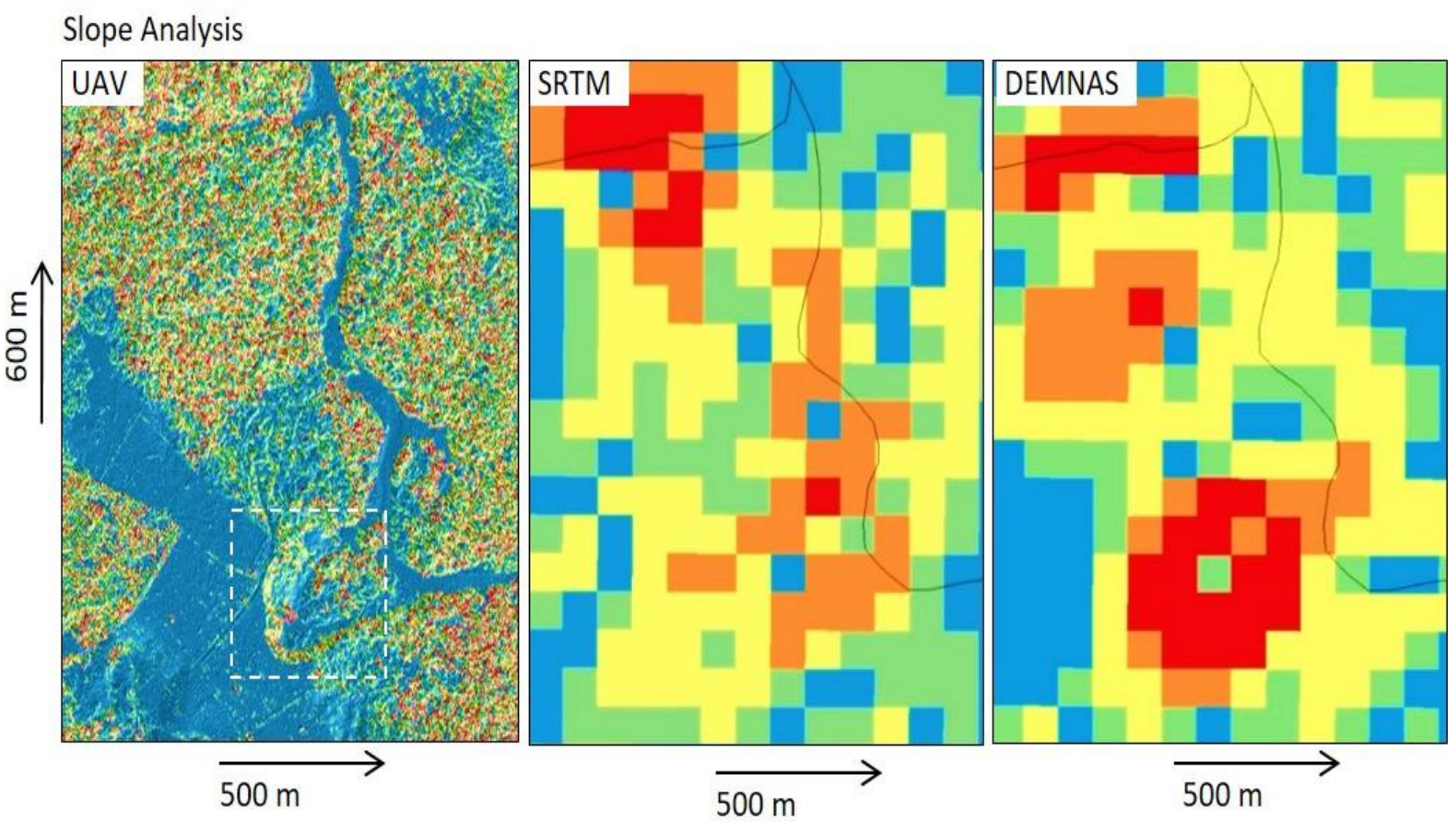

Slope (degree)

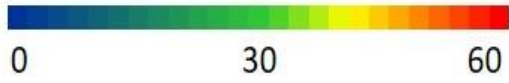

Figure 5. The comparison of the slope data (in degrees) from the results of calculations using (a) UAV, (b) SRTM, and (c) DEMNAS with the same color and scale. The white line is the coal outcrop area.

\section{UAV as Base Maps of geomagnetic}

The 3D geophysical measurements change in the $x$-direction as a function of latitude and the y-direction as a longitude. Many geophysical instruments are possible to be measured in a 3D direction, likely the gravity method, magnetic, seismology, and electromagnetic. To facilities 3D interpretation, field description as the topography is always needed for overlaid to field data measurements. Figure 6 shows the difference in UAV topography compared to
Global data (SRTM and DEMNAS); the data is also overlaid with magnetic geophysical data to estimate the subsurface coal structures. The magnetic field intensity obtained from the PPM magnetometer is due to variations in magnetized objects below the earth's surface (susceptibility). The magnetic field intensity values range from 400 to -110 nano Tesla (nT). The data can be interpreted that the high coal content is characterized by high magnetic field intensity. 

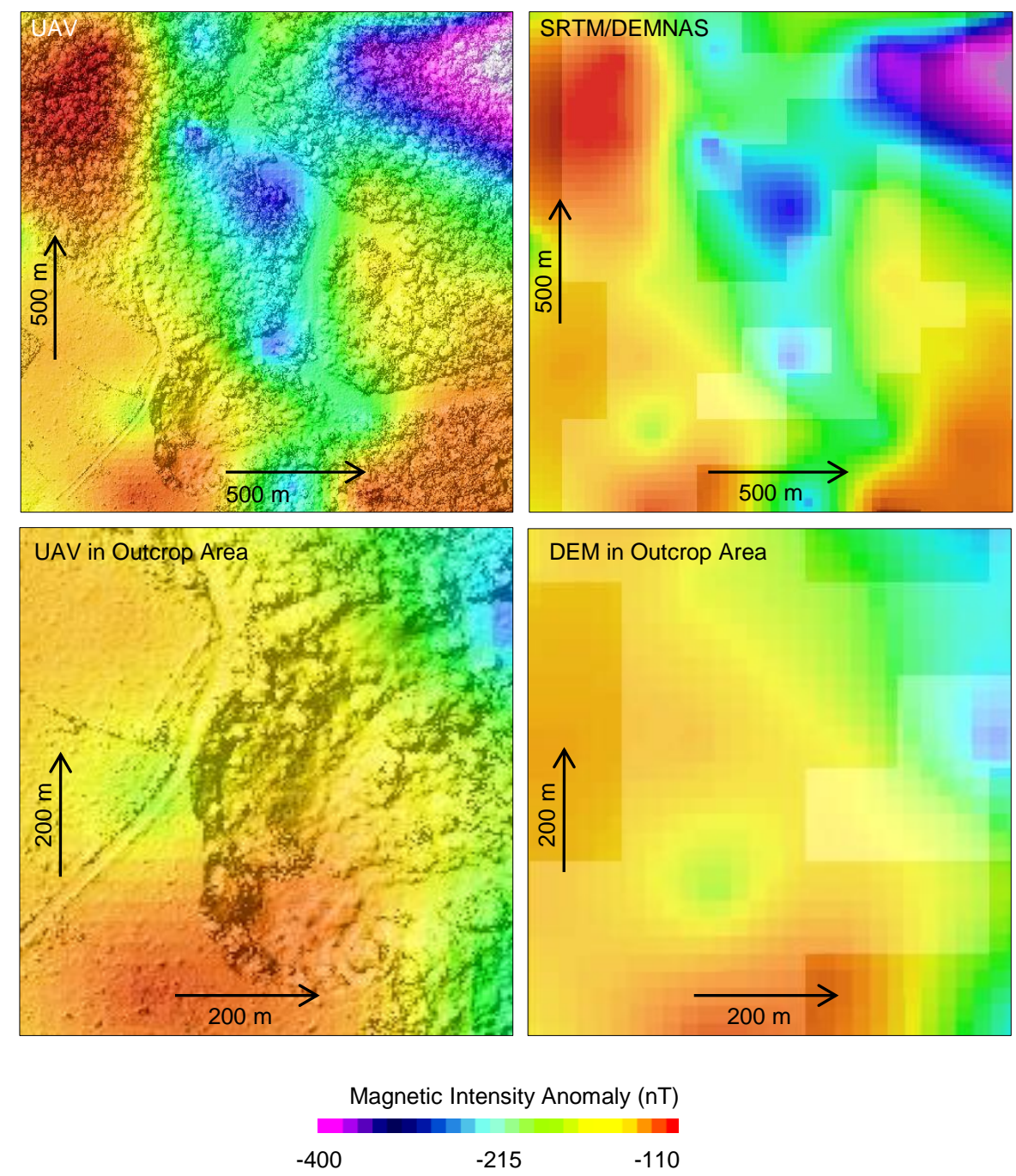

Figure 6. Comparison of topographic data from the UAV survey on the left and SRTM/DEMNAS on the right, the data topographic data from both surveys are used as a

base map for interpretation of geomagnetic in the mapping of coal distribution. In comparison, the lower-left overlays magnetic data with UAV in the outcrop area only, and the right side uses SRTM/DEMNAS data.

The overlaid SRTM or DEMNAS topography with the magnetic data cannot show the difference between each anomaly in the surface, such as rivers and surrounding conditions. The global data does not explain field descriptions at the magnetic interpretation, especially in the local areas of coal outcrops $(50 \times 30 \mathrm{~m})$. Meanwhile, UAV topography results in the geographical condition of the survey area, for example, in the river area characterized by low magnetic intensity from -400 to -200 nT. At the same time, the UAV data can distinguish the topography effect of the anomaly, so it is beneficial in data interpretation. The high topography area in the Westside is dominated by high magnetic field intensity, while on the Eastside is shown by the low anomaly. The magnetic field intensity data is not directly proportional to the topography, but the magnetic field appears in response to differences in the susceptibility of subsurface rocks. The coal material is characterized by a high magnetic field classified as a ferromagnetic object and influenced by magnetic fields (Pal et al., 2016).

Furthermore, the local objects such as the coal outcrop area with a $50 \times 50 \mathrm{~m}$, the 
UAV topography is also able to provide the geographical conditions of the measurement area. It will be helped the geophysicists to interpret the magnetic intensity with the topographic information as the site description. Based on data analysis and comparing to global DEM, it can be concluded the UAV topography is very potential to be used as base maps in presenting the geophysical data, this is due to the high resolution of the data, namely 2.5 $\mathrm{cm} / \mathrm{px}$ for a flying altitude of $100 \mathrm{~m}$ above the surface.

\section{CONCLUSION}

Topography has become a standard parameter for studying various geological phenomena in seismology and geophysical methods that have used topography as a base map to determine the field description in data interpretation. For regional studies, the global DEM is relatively often used, while in the local studies, the global data are not useful to apply. In the research, we have used the UAV system to produce a high resolution of topography data $(2.5 \mathrm{~cm} / \mathrm{px})$. The UAV is used to obtain the topography covering the magnetic survey as a nearsurface geophysical method for mapping the sub-surface's coal volume. For data comparison, we also compared the UAV data with global DEM, namely SRTM (30 $\mathrm{m} / \mathrm{px})$ and DEMNAS $(8.25 \mathrm{~m} / \mathrm{px})$. The UAV system performed the topographic data in the DSM, DTM, and orthomozaik images based on processing, which has to combine 630 frames into one image. The DSM shows the topography of the research area is in the range of 120 to $250 \mathrm{~m}$. The UAV topography can also be used for slope analysis that ranges from 0 - 60 degrees. UAV data overlay with a total magnetic field intensity (nT) from magnetic measurement shows the topography can be used as a base map. The topography is useful for explaining a field description in the interpretation of nearsurface structure for geophysical study, even in more local areas such as rivers with dimensions of $2 \times 2 \mathrm{~m}$, hills (100x100 m), and coal outcrops $(50 \times 50 \mathrm{~m})$ can be mapped very well.

\section{ACKNOWLEDGMENT}

We would like to thanks students of the Geophysics Engineering Tour (GET) 2018 who contributed to the data collection. We also thank Badrul Munir as a laboratory assistant who also helped a lot in field observation.

\section{REFERENCE LIST}

Ahmad, M. J., Ahmad, A., and Kanniah, K. (2018). Large Scale Topography Mapping Based on Unmanned Aerial Vehicle and Aerial Photogrammetric Technique. Department of Geoinformation, Faculty of Geoinformation \& Real Estate Universiti Teknologi Malaysia. IOP Conf. Series: Earth and Environmental Science: 169.

Bailey, J.E., Self, S., Wooller, L.K. And MouginisMark, P.J. (2007). Discrimination of Fluvial and Eolian Features on Large Ignimbrite Sheets Around La Pacana Caldera, Chile, Using Landsat And Srtm-Derived Dem. Remote Sensing of Environment, 108, Pp. 24-41.

Blistan, P., Kovanic, L., Zeliznakova, V., Palkova, J. (2016). Using UAV photogrammetry to document rock outcrops.Acta Montan. Slovaca, 21, 154161.

Chi, Y., Ya-Fen Lee, Shang-En Tsai. (2006). Study on High Accuracy Topographic Mapping via UAV-based Images. IOP Conference Series: Earth and Environmental Science.

DJI (2018), Mavic Pro Release Notes, 2018.

Gurugnanam. B and Kalaivanan. K. (2014). Analysis Of Digital Elevation Model Of Kolli Hill, South India Using Shuttle Radar Topography Mission Data And GIS Techniques, International Journal of Scientific Research, Volume: 3, Issue: 6. ISSN No: 2319-3484.

Mancini, F., Dubbini, M., Gatteli, M., Stecchi, F., Fabbri, S. and Gabbianelli, G. (2013). Using Unmanned Aerial Vehicles (UAV) for High-Resolution Reconstruction of Topography: The Structure from Motion Approach on 
Coastal Environments. Remote Sens. 2013, 5, 6880-6898; doi:10.3390/rs5126880.

Marwan, Yanis,M , Idroes R and Ismail, N, (2019). 2D inversion and Static Shift of MT and TEM Data for Imaging the Geothermal Resources of Seulawah Agam Volcano, Indonesia., Internasional Journal of GEOMATE. Vol 17, Issue 62,pp. 173-180.

Masoud, A. and Koike, K. (2006). Tectonic Architecture through Landsat-7 Etmp/Srtmdem-Derived Lineaments and Relationships To The Hydrogeologic Settings In Siwaregion, Nw Egypt. Journal of African Earth Sciences, 45, Pp. 467-477.

Masoud, A. and Koike, K. (2011). Autodetection and integration of tectonically significant lineaments from SRTM DEM and remotely-sensed geophysical data. ISPRS Journal of Photogrammetry and Remote Sensing, 66.6: 818-832.

Muksin, U., Bauer, K., Muzli, M., Ryberg, T., Nurdin, I., Masturiyono, M., \& Weber, M. (2019). AcehSeis project provides insights into the detailed seismicity distribution and relation to fault structures in Central Aceh, Northern Sumatra. Journal of Asian Earth Sciences, 171, 20-27.

Pal, S. K., Vaish, J., Kumar, S., \& Bharti, A. K. (2016). Coal fire mapping of East Basuria Colliery, Jharia coalfield using vertical derivative technique of magnetic data. Journal of Earth System Science, 125(1), 165-178.

Sanders, B. F. (2007). Evaluation of On-Line Dems for Flood Inundation Modeling. Advances in Water Resources, 30, Pp. 1831-1843.

Shofiyanti, R. (2011). Teknologi Pesawat Tanpa Awak Untuk Pemetaan dan Pemantauan Tanaman dan Lahan Pertanian. Informatika Pertanian, Vol. 20 No.2, Desember 2011 : 58 - 64 .

USGS. (2015). Landsat 8 (L8) Data Users handbook, [online], dari: https://landsat.usgs.gov/documents/
Landsat8DataUsersHandbook.pdf. [3 Februari 2017].

Valeriano, M.M., Kuplich, T.M., Storino, M., Amaral, B.D., Mendes Jr, J.N. And Lima, D. J. (2006). Modeling Small Watersheds In Brazilian Amazonia With Shuttle Radar Topographic Mission-90 M Data. Computer and Geosciences, 32, Pp. 1169-1181.

Vallet, J., F. Panissod, C. Strecha, dan M. Tracol. (2011). Photogrammetric Performance of an Ultra Light Weight Swinglet, International Archives of the Photogrametri, Remote Sensing and spatial Information Science, Zurich, Swiss.

Van Zyl, J. J. (2001). The Shuttle Radar Topography Mission (SRTM): a breakthrough in remote sensing of topography. Acta Astronautica, 48(5-12), 559-565.

Watt, J., Ponce, D., Parsons, T., \& Hart, P. (2016). Missing link between the Hayward and Rodgers Creek faults. Science advances, 2(10), e1601441.

Yanis, M., Marwan. (2019, November). The potential use of satellite gravity data for oil prospecting in Tanimbar Basin, Eastern Indonesia. In IOP Conference Series: Earth and Environmental Science (Vol. 364, No. 1, p. 012032). IOP Publishing.

Yanis, M., Marwan. Dan Kamalia, N. (2020). Aplikasi Satellite GEOSAT dan ERS sebagai metode alternatif Pengukuran Gravity Ground pada cekungan Hidrokarbon di Pulau Timur. Majalah Geografi Indonesia, 33(2), 1-9.

Zainal, M., Yanis, M., Darisma, D., \& Ismail, N. (2019, November). The determination of depth anomaly in archaeo-magnetic using an Euler deconvolution: Case study in Kuta Lubok fortress. In IOP Conference Series: Earth and Environmental Science (Vol. 364, No. 1, p. 012034). IOP Publishing.

Zhao, Q., Xu, X., Forsberg, R., \& Strykowski, G. (2018). Improvement of downward continuation values of airborne gravity data in Taiwan. Remote Sensing, 10(12), 1951. 